\title{
DECIDUOUS BROAD-LEAVED SPECIES (QUERCUS ROBUR, TILIA CORDATA, ACER PLATANOIDES AND ULMUS LAEVIS) FOREST STAND PRODUCTIVITY IN LATVIA
}

\author{
Guntars Šṇepsts", Jānis Donis, Dārta Kaupe, and Māris Laiviṇš \\ Latvian State Forest Research Institute "Silava", 111 Rīga Str., Salaspils, LV-2169, LATVIA \\ \# Corresponding author, guntars.snepsts@ silava.Iv
}

Communicated by Āris Jansons

\begin{abstract}
Climate forecasts indicate that in the future the climate will become more and more suitable for growth of broad-leaved tree species in Latvia. It is therefore very important to recognise and understand the growth potential of these broad-leaved stands in Latvia and the factors affecting the increment of growing stock. The results of the study showed high volume yield, as already 60- to 80-year-old stand stock could reach 500-600 $\mathrm{m}^{3} \cdot \mathrm{ha}^{-1}$, and in later years even $700-1000 \mathrm{~m}^{3} \cdot \mathrm{ha}^{-1}$. Similarly, the results of our study showed that the increment of the stock and growth potential of individual forest elements varied significantly between the various broad-leaved species. Significant factors were the age of the forest stand or forest element (a set of trees of the same species, in one layer and belonging to one generation), the indicators of competition (basal area and/or relative density) and the indicators of the social status of the forest element, namely, the ratio of the mean diameter of the forest element and the mean diameter of the dominant species of the upper layer of the stand and the sum of the basal area of the larger forest elements). No significant differences were found in growing stock and growth potential between monospecies and mixed stands and between simple and complex stands, neither at the level of the stands, nor at the level of the individual forest element.
\end{abstract}

Key words: broad-leaved species, growth and yield, increment.

\section{INTRODUCTION}

Climate is one of the main limiting factors affecting the distribution of tree species and forest yield (Walther et al., 2002; Thuiller, 2004). Due to climate change, it is generally predicted that the climate in Latvia will become warmer and that the growing conditions in the near future will become more similar to those in Lithuania, the southern part of Sweden or the eastern part of the Poland, and later in the future - like in the central part of Poland or the western part of Germany (Jansons et al., 2015). As a result, these climate projections indicate that in the near and distant future the climate will become increasingly suitable for broad-leaved tree growth in Northern Europe (Hemery et at., 2010) and thus also in Latvia. Therefore, it is very important to already identify and understand the potential of these broad-leaved forest in Latvia. Unfortunately, for most broad-leaved tree species there is little information on the yield and growth potential, but oak Quercus robur and ash Fraxinus excelsior could be exceptions. Tree species such as lime Tilia cordata, maple Acer platanoides, and fluttering elm Ulmus laevis in Latvia have still been little studied, most likely because stands of these species are rare in Latvia - oak stands $0.33 \%$, lime stands $0.07 \%$, fluttering elm and wych elm stands $0.07 \%$ and maple stands $0.53 \%$ (State Forest Service, 2020). Studies elsewhere in Europe show that oak and lime stands are able to be productive with stock up to 700-900 $\mathrm{m}^{3} \cdot \mathrm{ha}^{-1}$ (Shvidenko et al., 2008; De Jaegere et al., 2016; Dobrovolny et al., 2017). In Lithuania, on the most fertile site types, in 70- to 100-year-old lime stands the mean accumulated growing stock volume comprises 300-330 $\mathrm{m}^{3} \cdot \mathrm{ha}^{-1}$ (Semaškienè, 2006). However, we did not find information on the productivity of old (over 60 years old) maple and elm stands. Therefore, in this study, our aim was to provide insight into the productivity of stands of these broad-leaved species that were less frequently studied 
in Latvia, as well as the growth potential of stands and individual forest elements and the affecting factors. In this study, the hypothesis was that in Latvia it is already possible to grow productive broad-leaved stands, and that their productivity depends on the age, density, and structure of the stand.

\section{MATERIALS AND METHODS}

Study area and sampling. This study uses data on 46 stands - 17 oak stands, 9 lime stands, 11 maple stands and 9 fluttering elm stands (Fig. 1). This study also analysed data on 116 individual forest elements - 32 oaks, 37 limes, 34 maples, and 13 elms.

One circular plot of size $706.5 \mathrm{~m}^{2}(\mathrm{R}=15 \mathrm{~m})$ was placed in each stand. All live trees with a height of at least $5 \mathrm{~m}$ were surveyed in the plot. For all surveyed trees, local coordinates were recorded (distance $( \pm 0.1 \mathrm{~cm})$ and direction $\left( \pm 0.5^{\circ}\right)$ from the centre of the plot), as well as the diameter at breast height $( \pm 0.1 \mathrm{~cm})$, and tree height $( \pm 0.1 \mathrm{~m})$. For characterising the growth of the stand in plots, increment cores were taken with Presler's increment borer at height $1.3 \mathrm{~m}$. In the laboratory, air-dried cores were mounted on fixation planks and gradually sanded, decreasing roughness of the sandpaper from 100 to 400 grains per inch, using a hand-sanding machine. Radial growth measurement was carried out using LINTAB IV. TSAP Win Scientific 0.55 softwre was used for data preprocessing.

Stand parameter calculation. Forest inventory indicators of individual forest elements were estimated for each plot or stand - mean diameter, mean height, number of trees per ha, basal area, standing volume and mean periodic increment of growing stock over the last ten years of the trees living at the time of measurement. The study treats as one forest element a set of trees of the same species, in one layer and belonging to one generation. The equation developed by I. Liepa was used to calculate the volume of individual trees (Liepa, 1996):

$V=\psi \cdot H^{\alpha} \cdot D^{(\beta \cdot \lg H+\varphi)}$, where

$\mathrm{V}$ - tree volume, $\mathrm{m}^{3} ; \mathrm{H}$ - tree height, $\mathrm{m} ; \mathrm{D}$ - tree diameter at $1.3 \mathrm{~m}$ high, $\mathrm{cm} ; \psi, \alpha, \beta, \varphi-$ coefficients (Table 1 ).

Mean periodic increment of growing stock over the last ten years of trees living at the time of measurement was calculated using the following equation (Liepa, 1996):

$$
\begin{gathered}
Z_{V}=\psi \cdot H^{\alpha-1} \cdot D^{(\beta \cdot \lg H+\varphi-1)} \cdot\left[D \cdot Z_{H} \cdot(\beta \cdot \lg D+\alpha)+\right. \\
\left.+0.1 \cdot H \cdot Z_{D} \cdot(\beta \cdot \lg H+\alpha)\right], \text { where }
\end{gathered}
$$

$\mathrm{Z}_{\mathrm{V}}$ - mean periodic increment in stock over the last ten years of trees living at the time of measurement, $\mathrm{m}^{3} ; \mathrm{H}-$ tree height, $\mathrm{m} ; \mathrm{Z}_{\mathrm{H}}-$ tree height increment, $\mathrm{m}$; $\mathrm{D}$ - tree diameter at $1.3 \mathrm{~m}$ height, $\mathrm{cm} ; \mathrm{Z}_{\mathrm{D}}$ - tree diameter at $1.3 \mathrm{~m}$ height increment, $\mathrm{mm} ; \psi, \alpha, \beta, \varphi-$ coefficients (Table 1).

The mean diameter increment was calculated as double radial growth, corrected by the bark thickness coefficient

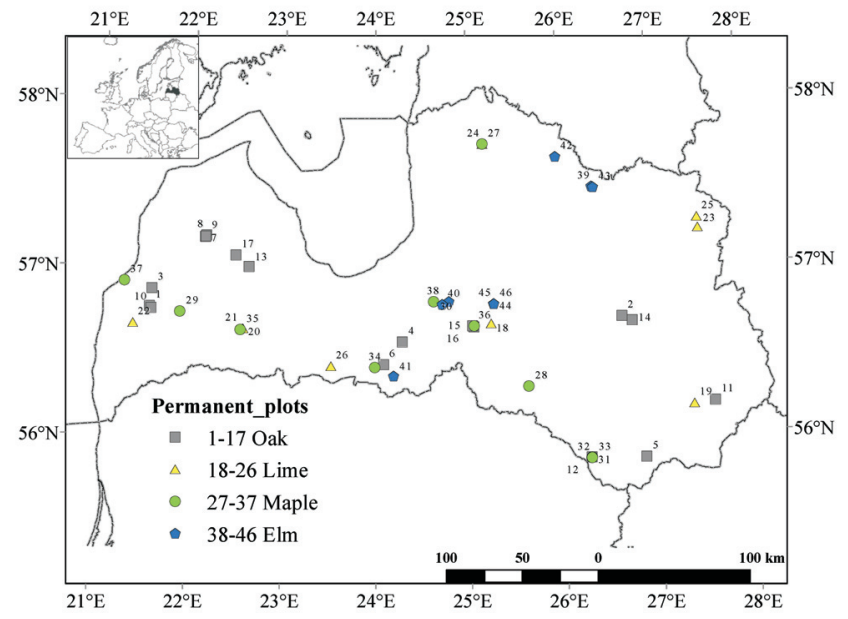

Fig. 1. Location of study plots in Latvia.

Table 1. Equation coefficients for calculating growing stock and increment of the growing stock (Liepa, 1996)

\begin{tabular}{lccccc}
\hline \multicolumn{1}{c}{ Species } & $\Psi$ & $\alpha$ & $\beta$ & $\phi$ \\
\hline Pine & $1.6541 \mathrm{E}-04$ & 0.56582 & 0.25924 & 1.59689 \\
Spruce and other conifers & $2.3106 \mathrm{E}-04$ & 0.78193 & 0.34175 & 1.18811 \\
Birch, lime, maple, cherry & $9.0900 \mathrm{E}-05$ & 0.71677 & 0.16692 & 1.75701 \\
Black alder & $7.9500 \mathrm{E}-05$ & 0.77095 & 0.13505 & 1.80715 \\
Aspen and poplar & $5.0200 \mathrm{E}-05$ & 0.92625 & 0.02221 & 1.95538 \\
Grey alder and other & $7.4500 \mathrm{E}-05$ & 0.81295 & 0.06935 & 1.85346 \\
deciduous & & & & \\
Oak, beech, hornbeam & $1.3818 \mathrm{E}-04$ & 0.56512 & 0.14732 & 1.81336 \\
Ash, elm & $8.5300 \mathrm{E}-05$ & 0.73077 & 0.06820 & 1.91124
\end{tabular}

(Liepa, 1996). The increase in height of the last ten years was calculated using the GADA equation (Donis and Šnepsts, 2019):

$$
\begin{aligned}
& Z_{H}=H-1.3+ \\
& +\frac{(A-10)^{\alpha_{1}}}{\alpha_{2}+100 \cdot \alpha_{3} \cdot \frac{\frac{A^{\alpha}}{H-1.3}-\alpha_{2}}{100 \cdot \alpha_{3}+A^{\alpha_{1}}}+\frac{\frac{A^{\alpha_{1}}}{H-1.3}-\alpha_{2}}{100 \cdot \alpha_{3}+A^{\alpha_{1}}}(A-10)^{\alpha_{1}}} \text {, where }
\end{aligned}
$$

$\mathrm{Z}_{\mathrm{H}}$ - tree height increment in last 10 years, $\mathrm{m} ; \mathrm{H}$ - tree height, $\mathrm{m} ; \mathrm{A}-$ tree age at breast height, years; $\alpha_{1-3}-$ coefficients (Table 2).

The increase (increment) in stock was calculated for each tree by the sum of the growth of trees of a separate forest element, or a separate forest element $\left(Z_{M}\right)$.

In order to characterise the growth potential in the study, the increase in the stock of a stand or a separate forest element was estimated for basal area of a stand and separate forest element. Thus, an indicator was obtained to characterise the production of $\mathrm{m}^{3}$ of wood per unit of basal area $\left(\mathrm{m}^{2}\right)$ to compare plots and stands and also separate forest elements. The study examined as dependent variables the mean periodic increment in growing stock of living trees over the last ten years and the ratio of this increase to the basal area of a stand or forest element. In addition, both these indicators were examined at both stand and forest ele- 
Table 2. Equation coefficients for calculating height increment

\begin{tabular}{lcccc}
\hline \multicolumn{1}{c|}{ Species } & $\alpha 1$ & $\alpha 2$ & $\alpha 3$ \\
\hline Pine & 1.1570 & -27.0403 & 16.4512 \\
Spruce and other conifers & 1.2839 & -47.3493 & 23.6008 \\
Birch, lime, elm, maple, cherry & 1.2541 & -47.4748 & 21.7259 \\
Black alder & 1.1821 & -53.1708 & 22.4722 \\
Aspen and poplar & 1.2756 & -9.7338 & 6.2226 \\
Grey alder and other deciduous & 1.2323 & -54.6704 & 16.4896 \\
Oak, beech, hornbeam & 1.1811 & -42.5972 & 21.1092 \\
Ash & 1.2900 & -38.1425 & 20.1591
\end{tabular}

Coefficients from Donis et al. (2019)

ment levels. The study examined whether this growth potential is similar among broad-leaved species and whether the structure of the stand affects the growth potential. The Gini index and Shannon index were used to describe stand structure (Lexerød and Eid, 2006), and stands were divided into monospecies and mixed stands and simple and complex stands. When calculating the Gini index, the height of trees and the number of trees were taken into account, thus characterising the condition of the tree stand (the lower the coefficient, the more homogeneous the structure of the tree stand). Shannon's index was calculated taking into account tree species, generation and number of trees. For the purposes of this study, stands with a share of the dominant species of at least $80 \%$ of the total stock were classified as monospecies. Stands with a growing stock of at least 20 $\mathrm{m}^{3} \cdot \mathrm{ha}^{-1}$ in the $2^{\text {nd }}$ and $3^{\text {rd }}$ layer were classified as complex, and other stands as simple stands. Similarly, the age and average diameter of the dominant tree species, the basal area and relative density of the stand were tested as dependent variables to examine relationship with growth of the stand. In the analysis at the forest element level, in addition to the indicators of the structure of the stand and the species of the forest element, dependent variables included the basal area of the stand and the relative density of the $1^{\text {st }}$ (dominant) layer, the average diameter of the forest element, age, the basal area, the relative diameter in relation to the average diameter of the dominant tree species of the stand and the sum of the basal area for elements larger than the particular forest element. The relative density of the first layer (canopy layer) of the stand was calculated as the ratio of the number of trees in the first layer to the maximum number of trees. Maximum number of trees was calculated using the equation (Donis, 2015):

$N_{\max }=\sum \beta_{1} \cdot d_{i}^{\beta_{2}} \cdot h_{i}^{\beta_{3}}$, where

$\mathrm{N}_{\text {max }}$ - maximal tree number per ha; $\mathrm{d}$ - tree mean diameter at $1.3 \mathrm{~m}$ height for each element, $\mathrm{cm} ; \mathrm{H}$ - tree mean height for each element; $\mathrm{m}, \beta_{1-3}-$ coefficients (Table 3 ).

Forest inventory parameters for the stand and individual stand elements were calculated in MS Excel.

Data analysis. In order to characterise the forest stand stock and compare it between different dominant species depending on age and thus characterise the potential of dif-
Table 3. Equation coefficients for calculating maximum number of trees

\begin{tabular}{lcccc}
\hline \multicolumn{1}{c|}{ Species } & $\beta 1$ & $\beta 2$ & $\beta 3$ \\
\hline Pine & 83570 & -1.366 & -0.069 \\
Spruce and other conifers & 103106 & -1.381 & -0.103 \\
Birch, lime, elm, maple, cherry & 144400 & -1.357 & -0.302 \\
Black alder, grey alder, aspen, poplar & 197511 & -1.314 & -0.339 \\
and other deciduous & & & \\
Oak & 83570 & -1.366 & -0.069 \\
Ash, beech, hornbeam & 103106 & -1.381 & -0.103
\end{tabular}

Coefficients from Donis et al. (2015)

ferent broad-leaved tree species in Latvia, stands were divided into five age groups: 1) up to 40 years, 2) 41-80 years, 3) 81-120 years, 4) 121-160 years, 5) older than 160 years. For each age group, the mean, minimum, maximum and standard error of the stock was calculated.

Analysis of factors influencing growth was performed in SPSS for Windows using the generalised Estimating Equations tool. Growth $\left(Z_{M}\right)$ and growth potential $\left(Z_{M} G\right)$ values were natural logarithmic transformed to give $\ln \left(Z_{M}\right)$ and $\ln \left(Z_{\mathrm{M}} \mathrm{G}\right)$. When analysing the increment at the stand level, "location" was used as a subject variable. In the analysis at forest element level, the location and object were used as subject variables. In total, there were seven locations where several objects were located relatively close to each other: Ciecere (2 objects), Jēkabkalns (2), Moricsala (3), Rauda (4), Skrīveri (3), Smidži (2) un Vērene (3). The analysis assumed that the remaining 27 objects were located in separate locations. Factors tested in the study are summarised in Table 4. Multicollinearity between explanatory variables ws assessed using the Variance Inflation Factor (VIF); variables with VIF $>5$ were excluded from the final model.

The final model included species and age of the stand or forest element, respectively, and other tested factors that were statistically significant $(p<0.05)$ and for which no multicollinearity was found $(\mathrm{SWF}<5)$.

\section{RESULTS}

In plots in oak stands, the stock of living trees ranged from $84.5-774.8 \mathrm{~m}^{3} \cdot \mathrm{ha}^{-1}$, in lime stands from 418.7-1127.1 $\mathrm{m}^{3} \cdot \mathrm{ha}^{-1}$, in maple stands from 246.6-559.1 $\mathrm{m}^{3} \cdot \mathrm{ha}^{-1}$ and in elm stands from $306.5-634.4 \mathrm{~m}^{3} \cdot \mathrm{ha}^{-1}$. The average periodic increment of live trees in oak stands calculated for the last ten years of these plots was from $4.7-15.6 \mathrm{~m}^{3} \mathrm{ha}^{-1}$ year, in lime stands is from 8.9-14.5 $\mathrm{m}^{3} \mathrm{ha}^{-1}$ year, maple stands from 7.9-22.7 $\mathrm{m}^{3} \mathrm{ha}^{-1}$ per year, and in elm stands from $8.8-18.0 \mathrm{~m}^{3} \mathrm{ha}^{-1}$ year (Table 5).

When dividing stands into age groups (40 years), there was a tendency for the stock of lime stands to be larger than in stands of other species. However, the number of stands in each age group is small, indicating only trends and not statistically significant differences. 
Table 4. Description of explanatory variables tested in the model. Number of observations for categorical variables; mean \pm standard deviation (SD) for continuous variables

\begin{tabular}{|c|c|c|c|}
\hline Abbreviation & Description & Classes & $\begin{array}{l}\text { Number of sample plots } \\
\text { or elements / mean } \pm \text { SD }\end{array}$ \\
\hline \multirow[t]{4}{*}{ Dominant_species } & Dominant tree species ( $>50 \%$ of stand volume) & 01_Oak & 17 \\
\hline & & 02_Lime & 9 \\
\hline & & 03_Maple & 11 \\
\hline & & 04_Elm & 9 \\
\hline \multirow[t]{2}{*}{ Stand_composition } & Composition of canopy-layer & $01-$ monodominant & 23 \\
\hline & & $\begin{array}{l}02-\text { mixed }(<80 \% \text { of standing } \\
\text { volume })\end{array}$ & 23 \\
\hline \multirow[t]{2}{*}{ Stand_structure } & Structure of canopy-layer & 01 - homogeny & 25 \\
\hline & & $\begin{array}{l}02 \text { - heterogenic (stand lower } \\
\text { layer volume } \geq 20 \mathrm{~m}^{3} \mathrm{ha}^{-1} \text { ) }\end{array}$ & 21 \\
\hline Gini & $\begin{array}{l}\text { Structure index calculate by tree height, lower values indicate } \\
\text { more homogenous stand }\end{array}$ & & $0.24 \pm 0.06$ \\
\hline Shannon & $\begin{array}{l}\text { Diversity index, calculate by tree species and element genera- } \\
\text { tion }\end{array}$ & & $1.18 \pm 0.48$ \\
\hline A & Age of dominant tree species (years) & & $107.51 \pm 53.43$ \\
\hline $\mathrm{D}$ & Mean diameter of the dominant species trees $(\mathrm{cm})$ & & $42.96 \pm 16.45$ \\
\hline $\mathrm{BA}$ & Stand basal area $\left(\mathrm{m}^{2} \mathrm{ha}^{-1}\right)$ & & $41.46 \pm 11.42$ \\
\hline $\mathrm{RD}$ & $\begin{array}{l}\text { Stand relative density (calculated as ratio between stand num- } \\
\text { ber of trees per hectare and the maximum stand number of } \\
\text { trees per hectare for a species and mean height) }\end{array}$ & & $0.78 \pm 0.27$ \\
\hline \multirow[t]{4}{*}{ species } & Tree species & 01_Oak & 32 \\
\hline & & 02_Lime & 37 \\
\hline & & 03_Maple & 34 \\
\hline & & 04_Elm & 13 \\
\hline $\mathrm{a}$ & Age of element tree (years) & & $82.06 \pm 52.17$ \\
\hline $\mathrm{d}$ & Mean diameter of the element trees $(\mathrm{cm})$ & & $30.51 \pm 18.71$ \\
\hline $\mathrm{RdD}$ & $\begin{array}{l}\text { Relative diameter of the element trees (calculated as ratio be- } \\
\text { tween element mean diameter (d) and mean diameter of the } \\
\text { dominant species trees (D)) }\end{array}$ & & $0.73 \pm 0.41$ \\
\hline ba & Element basal area $\left(\mathrm{m}^{2} \mathrm{ha}^{-1}\right)$ & & $13.62 \pm 15.35$ \\
\hline BAL & Basal area in larger elements $\left(\mathrm{m}^{2} \mathrm{ha}^{-1}\right)$ & & $17.27 \pm 15.84$ \\
\hline
\end{tabular}

Nevertheless, in the age group 121-160 years, in lime stands the growing stock was significantly $(\alpha=0.05)$ higher than in oak stands (Table 6, Fig. 2). For oak stands, growing stock in age groups over 80 years did not differ significantly $(\alpha=0.05)$.

The average increment potential of live trees in oak stands calculated for the last ten years was from $0.13-0.55 \mathrm{~m}^{3} \cdot \mathrm{ha}^{-1}$ year, in lime stands from $0.17-0.28 \mathrm{~m}^{3} \cdot \mathrm{ha}^{-1} \cdot$ year, maple stands from $0.27-0.68 \mathrm{~m}^{3} \cdot \mathrm{ha}^{-1}$ per year, and in elm stands from $0.21-0.48 \mathrm{~m}^{3} \cdot \mathrm{ha}^{-1} \cdot$ year (Table 5 ).

Increment potential of the forest elements depending on species and breast height age is shown in Figure 3. We found that the increment of the growing stock over the last ten years was significantly dependent on the dominant tree species ( $p$-value 0.012). Increment in the growing stock in maple stands was significantly higher than in oak stands, but no significant differences were found between other species combinations. Similarly, the increment of the growing stock over the last ten years was significantly smaller in older age groups, and significantly higher in stands with a larger basal area (Table 7). The final model for estimation of the increment of the growing stock over the last ten years retained only the relevant $(p<0.05)$ factors (Table 8$)$.

Significant differences ( $p=0.021)$ were found between the different species for growth potential or increase in stock per unit of basal area. In oak stands, growth potential was significantly lower than in lime $(p=0.004)$ and maple $(p<$ 0.001 ) stands, but no significant differences in growth potential were observed among other pairs of species. Growth potential was significantly related to the age of the stand $(p<0.001)$; in older stands it was significantly less than in younger stands. At the $90 \%$ confidence level, the relative density of the first layer of the stand $(p=0.051)$ was also an important factor influencing growth potential; basal area was lower in denser stands than in less dense (sparser) stands. The final model for estimation of growth potential in broad-leaved tree stands included all factors within the $90 \%$ confidence interval and also the age of the element (Table 8).

Our calculations showed that at the level of individual forest elements, the increase in growing stock over the last ten years differed significantly $(p \leq 0.05)$ between broad-leaved 
Table 5. Characteristics of sample plots

\begin{tabular}{|c|c|c|c|c|c|c|c|}
\hline Species & Parameter & $\mathrm{A}$ & $\mathrm{D}$ & $\mathrm{H}$ & $\mathrm{M}$ & $\mathrm{Zm}$ & $\mathrm{Zm} / \mathrm{G}$ \\
\hline \multirow{7}{*}{$\begin{array}{l}\text { Oak } \\
\text { (Quercus robur) }\end{array}$} & Mean & 146.0 & 50.8 & 27.0 & 504.5 & 8.2 & 0.22 \\
\hline & Standard error & 12.0 & 4.1 & 1.3 & 38.8 & 0.6 & 0.02 \\
\hline & Median & 157.8 & 52.1 & 28.2 & 522.1 & 7.8 & 0.20 \\
\hline & Standard deviation & 49.6 & 16.7 & 5.4 & 160.0 & 2.6 & 0.10 \\
\hline & Minimum & 30.1 & 13.3 & 10.5 & 84.5 & 4.7 & 0.13 \\
\hline & Maximum & 221.8 & 88.2 & 34.1 & 774.8 & 15.6 & 0.55 \\
\hline & Count & 17 & 17 & 17 & 17 & 17 & 17 \\
\hline \multirow{7}{*}{$\begin{array}{l}\text { Lime } \\
\text { (Tilia cordata) }\end{array}$} & Mean & 128.0 & 46.6 & 29.2 & 732.4 & 11.5 & 0.21 \\
\hline & Standard error & 13.5 & 5.5 & 2.2 & 72.4 & 0.8 & 0.01 \\
\hline & Median & 128.4 & 46.4 & 30.1 & 710.3 & 11.1 & 0.21 \\
\hline & Standard deviation & 40.4 & 16.4 & 6.7 & 217.2 & 2.3 & 0.04 \\
\hline & Minimum & 56.9 & 14.5 & 13.7 & 418.7 & 8.9 & 0.17 \\
\hline & Maximum & 185.8 & 70.5 & 36.9 & 1127.1 & 14.5 & 0.28 \\
\hline & Count & 9 & 9 & 9 & 9 & 9 & 9 \\
\hline \multirow{7}{*}{$\begin{array}{l}\text { Maple } \\
\text { (Acer platanoides) }\end{array}$} & Mean & 64.2 & 31.3 & 23.1 & 397.2 & 13.8 & 0.42 \\
\hline & Standard error & 8.1 & 3.9 & 1.5 & 33.2 & 1.3 & 0.04 \\
\hline & Median & 64.0 & 25.6 & 23.0 & 423.3 & 13.7 & 0.38 \\
\hline & Standard deviation & 26.8 & 13.0 & 4.9 & 110.1 & 4.2 & 0.12 \\
\hline & Minimum & 27.9 & 15.8 & 15.9 & 246.6 & 7.9 & 0.27 \\
\hline & Maximum & 123.0 & 56.5 & 32.3 & 559.1 & 22.7 & 0.68 \\
\hline & Count & 11 & 11 & 11 & 11 & 11 & 11 \\
\hline \multirow{7}{*}{$\begin{array}{l}\text { Elm } \\
\text { (Ulmus laevis) }\end{array}$} & Mean & 67.2 & 38.7 & 22.0 & 490.1 & 12.7 & 0.32 \\
\hline & Standard error & 7.9 & 3.9 & 1.2 & 36.4 & 1.2 & 0.03 \\
\hline & Median & 63.1 & 34.0 & 21.0 & 483.4 & 10.6 & 0.31 \\
\hline & Standard deviation & 23.7 & 11.6 & 3.7 & 109.1 & 3.6 & 0.08 \\
\hline & Minimum & 44.2 & 26.1 & 17.5 & 306.5 & 8.8 & 0.21 \\
\hline & Maximum & 124.0 & 58.8 & 28.0 & 634.4 & 18.0 & 0.48 \\
\hline & Count & 9 & 9 & 9 & 9 & 9 & 9 \\
\hline
\end{tabular}

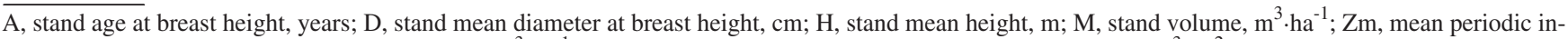
crement of living trees of period of last 10 years, $\mathrm{m}^{3} \cdot \mathrm{ha}^{-1}$. per year; $\mathrm{Zm} / \mathrm{G}$, volume increment per unit of basal area, $\mathrm{m}^{3} \cdot \mathrm{m}^{-2}$ per year.

Table 6. Growing stock $\left(\mathrm{m}^{3} \cdot \mathrm{ha}^{-1}\right)$ by age group (years) and dominant tree species

\begin{tabular}{c|l|c|c|c|c}
\hline Age group & \multicolumn{1}{|c}{ Parameter } & Oak & Lime & Maple & Elm \\
\hline \multirow{5}{*}{40} & Mean & 84.5 & & 280.8 & \\
& Standard error & & & 28.0 & \\
& Minimum & & & 252.9 & \\
& Maximum & & & 308.8 & \\
& Count & 1 & & 2 & \\
\hline \multirow{2}{*}{$41-80$} & Mean & & 579.3 & 402.3 & 496.4 \\
& Standard error & & 131.1 & 41.7 & 40.6 \\
& Minimum & & 448.2 & 246.6 & 306.5 \\
& Maximum & & 710.3 & 559.1 & 634.4 \\
& Count & & 2 & 7 & 8 \\
\hline \multirow{2}{*}{$81-120$} & Mean & 513.0 & & 493.6 & \\
& Standard error & 40.2 & & & \\
& Minimum & 402.5 & & & \\
& Maximum & 599.2 & & & \\
& Count & 5 & & 1 & \\
\hline \multirow{2}{*}{$121-160$} & Mean & 509.1 & 777.5 & 497.6 & 439.9 \\
& Standard error & 22.0 & 40.0 & & \\
& Minimum & 462.2 & 667.4 & & \\
& Maximum & 581.7 & 882.3 & & \\
& Count & 5 & 5 & 1 & 1
\end{tabular}

OOak $\square$ Lime $\Delta$ Maple $\bullet$ Elm

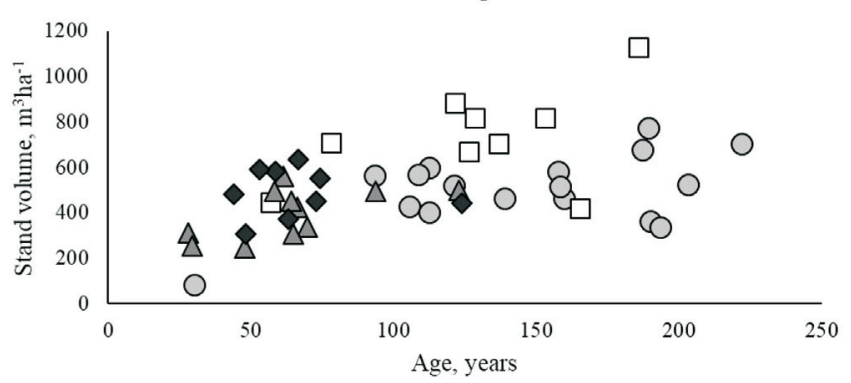

Fig. 2. Growing stock of the sample stands depending on dominant tree species in the $1^{\text {st }}$ layer and breast height age.

tree species. Maple had a significantly higher increment of growing stock over the past ten years than for oak, but for the rest of the species pairs the difference in growing stock increment was not significant. Similarly, at the level of individual forest elements, the increment of growing stock depended significantly on the basal area and relative diameter of the forest element (Table 9). The increment in growing stock was higher with a larger basal area of the forest element. Similarly, for forest elements with a higher relative mean diameter, the increment of growing stock is signifi- 
Table 7. Factors tested for assessment of the impact on the increment of growing stock at stand level

\begin{tabular}{c|lcccc}
\hline $\begin{array}{c}\text { Dependent } \\
\text { variable }\end{array}$ & \multicolumn{1}{c|}{ Source } & $\begin{array}{c}\text { Wald } \\
\text { Chi-Square }\end{array}$ & df & $p$-value \\
\hline Ln(Z $\left.\mathrm{Z}_{\mathrm{M}}\right)$ & (Intercept) & 138.141 & 1 & $<0.001$ \\
& Dominant_species & $\mathbf{1 0 . 9 8 3}$ & $\mathbf{3}$ & $\mathbf{0 . 0 1 2}$ \\
& Stand_composition & 0.172 & 1 & 0.678 \\
& Stand_structure & 2.634 & 1 & 0.105 \\
& Ln(A) & $\mathbf{4 4 . 0 4 4}$ & $\mathbf{1}$ & $<\mathbf{0 . 0 0 1}$ \\
& D & 0.017 & 1 & 0.895 \\
& BA & $\mathbf{1 8 . 0 0 5}$ & $\mathbf{1}$ & $<\mathbf{0 . 0 0 1}$ \\
& Gini & 0.000 & 1 & 0.991 \\
& Shannon & 0.080 & 1 & 0.777 \\
& RD & 1.939 & 1 & 0.164 \\
\hline Ln(Z $\left.\mathrm{Z}_{\mathrm{M}} \mathrm{G}\right)$ & (Intercept) & 44.619 & 1 & $<0.001$ \\
& Dominant_species & $\mathbf{9 . 7 1 9}$ & $\mathbf{3}$ & $\mathbf{0 . 0 2 1}$ \\
& Stand composition & 0.153 & 1 & 0.695 \\
& Stand_structure & 1.694 & 1 & 0.193 \\
LnA & $\mathbf{9 0 . 2 3 4}$ & $\mathbf{1}$ & $<\mathbf{0 . 0 0 1}$ \\
& D & 0.026 & 1 & 0.872 \\
BA & 0.031 & 1 & 0.860 \\
& Gini & 0.189 & 1 & 0.664 \\
& Shannon & 0.040 & 1 & 0.842 \\
& RD & $\mathbf{3 . 8 1 9}$ & $\mathbf{1}$ & $\mathbf{0 . 0 5 1}$ \\
& & & &
\end{tabular}

$\mathrm{Z}_{\mathrm{M}}$, increment of growing stock; $\mathrm{Z}_{\mathrm{MG}}$, growth potential; $\mathrm{A}$, age of dominant tree species; D, mean diameter of the dominant species trees; BA, stand basal area; Gini, structure index calculate by tree height; Shannon, diversity index, calculate by tree species and element generation; RD, stand relative density. Highlighted in bold are factors included in the final model

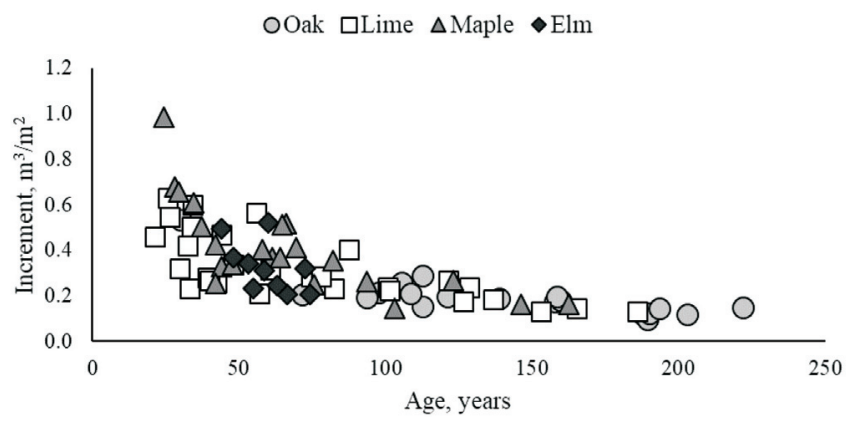

Fig. 3. Increment potential of the forest elements depending on species and breast height age.

cantly higher than for forest elements with a smaller relative diameter. The final model for the estimation of the increment of the growing stock over the last ten years of a single broad-leaved forest element included the age of the forest element and the relative density of the $1^{\text {st }}$ layer; although these factors were not significant, they nevertheless had biologically valid and logical values (Table 10). In addition, the effect of the relative density of the first layer of the stand in the final model was significant. The density of the first layer of the stand had a negative effect on the growth of the stock - the greater the density of the first layer, the smaller the increment of the growing stock of the forest element. Similarly, the age of the forest element had a negative
Table 8. Calculated coefficients for characterising the increment of growing stock at the stand level

\begin{tabular}{|c|c|c|c|c|c|}
\hline $\begin{array}{c}\text { Dependent } \\
\text { Variable }\end{array}$ & Source & Estimate & SE & $\begin{array}{c}\text { Wald } \\
\text { Chi-Square }\end{array}$ & $p$-value \\
\hline \multirow[t]{7}{*}{$\operatorname{Ln}\left(Z_{M}\right)$} & (Intercept) & 3.064 & 0.337 & 82.560 & $<0.001$ \\
\hline & $\begin{array}{l}\text { Dominant_species } \\
\text { oak }\end{array}$ & 0 & & & \\
\hline & $\begin{array}{l}\text { Dominant_species } \\
\text { lime }\end{array}$ & 0.035 & 0.106 & 0.106 & 0.745 \\
\hline & $\begin{array}{l}\text { Dominant_species } \\
\text { maple }\end{array}$ & 0.357 & 0.085 & 17.586 & $<0.001$ \\
\hline & $\begin{array}{l}\text { Dominant_species } \\
\text { elm }\end{array}$ & 0.157 & 0.119 & 1.731 & 0.188 \\
\hline & $\operatorname{Ln}(A)$ & -0.374 & 0.070 & 28.376 & $<0.001$ \\
\hline & $\mathrm{BA}$ & 0.021 & 0.003 & 42.261 & $<0.001$ \\
\hline \multirow[t]{7}{*}{$\operatorname{Ln}\left(Z_{M} G\right)$} & (Intercept) & 1.416 & 0.207 & 46.966 & $<0.001$ \\
\hline & $\begin{array}{l}\text { Dominant_species } \\
\text { oak }\end{array}$ & 0 & & & \\
\hline & $\begin{array}{l}\text { Dominant_species } \\
\text { lime }\end{array}$ & 0.190 & 0.066 & 8.359 & 0.004 \\
\hline & $\begin{array}{l}\text { Dominant_species } \\
\text { maple }\end{array}$ & 0.289 & 0.071 & 16.432 & $<0.001$ \\
\hline & $\begin{array}{l}\text { Dominant_species } \\
\text { elm }\end{array}$ & 0.090 & 0.087 & 1.070 & 0.301 \\
\hline & $\operatorname{Ln}(\mathrm{A})$ & -0.553 & 0.042 & 175.896 & $<0.001$ \\
\hline & $\mathrm{RD}$ & -0.469 & 0.090 & 27.093 & $<0.001$ \\
\hline
\end{tabular}

$\mathrm{Z}_{\mathrm{M}}$, increment of growing stock $\left(\mathrm{m}^{3} \cdot \mathrm{ha}^{-1}\right) ; \mathrm{Z}_{\mathrm{MG}}$, growth potential $\left(\mathrm{m}^{3} \cdot \mathrm{ha}^{-1} \cdot \mathrm{m}^{-2}\right)$; A, age of dominant tree species (years); BA, stand basal area $\left(\mathrm{m}^{2} \cdot \mathrm{ha}^{-1}\right) ; \mathrm{RD}$, stand relative density.

effect on the increment of growing stock — as the age increased, increment decreased.

Significant differences were found between broad-leaved tree species in increment of the growing stock per unit of basal area of an individual forest element. We found that the growth potential of oak was significantly lower than that of lime and maple. Significant effects were found for the density of the first layer of the stand, the age of the forest element and the relative diameter of the forest element in relation to the average diameter of the dominant tree species of the forest stand's first layer. The age of the forest element and the relative density of the first layer had a negative effect on the growth potential, i.e. the growth potential was lower at a higher age and at higher density. The relative diameter of a forest element had a positive effect on the growth potential - the larger the relative diameter, the greater the growth potential. The final model for estimation of growth potential for broad-leaved forest elements included the sum of the basal area of forest elements for elements larger than the specific forest element, as this factor was significant at the $90 \%$ confidence interval and had a biologically logical value in the final model.

\section{DISCUSSION}

The absolute majority of the plots were located in long-term unmanaged stands, especially on lake islands (Moricsala, Ciecere) or marsh islands (Liepu Island in Aizkraukle Bog). 
Table 9. Factors tested for assessment of the impact on the increment of growing stock at the forest element level

\begin{tabular}{|c|c|c|c|c|}
\hline $\begin{array}{c}\text { Dependent } \\
\text { variable }\end{array}$ & Source & $\begin{array}{c}\text { Wald } \\
\text { Chi-Square }\end{array}$ & df & $p$-value \\
\hline \multirow[t]{13}{*}{$\operatorname{Ln}\left(Z_{M}\right)$} & (Intercept) & 0.570 & 1 & 0.450 \\
\hline & species & 8.555 & 3 & 0.036 \\
\hline & Stand_composition & 0.433 & 1 & 0.511 \\
\hline & Stand_structure & 0.048 & 1 & 0.826 \\
\hline & BA & 0.038 & 1 & 0.846 \\
\hline & Gini & 1.721 & 1 & 0.190 \\
\hline & Shannon & 0.077 & 1 & 0.782 \\
\hline & RD & 2.441 & 1 & 0.118 \\
\hline & $\operatorname{Ln}(\mathbf{a})$ & 1.105 & 1 & 0.293 \\
\hline & $\mathrm{d}$ & 0.036 & 1 & 0.850 \\
\hline & ba & 42.597 & 1 & $<0.001$ \\
\hline & BAL & 0.060 & 1 & 0.807 \\
\hline & RdD & 18.227 & 1 & $<0.001$ \\
\hline \multirow[t]{13}{*}{$\operatorname{Ln}\left(\mathrm{Z}_{\mathrm{M}} \mathrm{G}\right)$} & (Intercept) & 29.134 & 1 & $<0.001$ \\
\hline & species & 16.945 & 3 & 0.001 \\
\hline & Stand_composition & 0.046 & 1 & 0.831 \\
\hline & Stand_structure & 0.450 & 1 & 0.503 \\
\hline & $\mathrm{BA}$ & 0.001 & 1 & 0.977 \\
\hline & Gini & 0.100 & 1 & 0.752 \\
\hline & Shannon & 0.935 & 1 & 0.334 \\
\hline & RD & 6.598 & 1 & 0.010 \\
\hline & $\operatorname{Ln}(\mathbf{a})$ & 66.624 & 1 & $<0.001$ \\
\hline & $\mathrm{d}$ & 0.372 & 1 & 0.542 \\
\hline & ba & 0.000 & 1 & 0.991 \\
\hline & BAL & 3.420 & 1 & 0.064 \\
\hline & RdD & 5.901 & 1 & 0.015 \\
\hline
\end{tabular}

$\mathrm{Z}_{\mathrm{M}}$, increment of growing stock; $\mathrm{bZ} \mathrm{M}_{\mathrm{M}} \mathrm{G}$, growth potential; Stand_composition, monodominant or mixed stands; Stand_structure, homogeny or heterogenic stands; BA, stand basal area; Gini, structure index calculate by tree height; Shannon, diversity index, calculate by tree species and element generation; RD, stand relative density; A, age of element tree; d, mean diameter of element trees; RdD, relative diameter of the element trees (calculated as ratio between element mean diameter and mean diameter of the dominant species trees); ba, element basal area; BAL, basal area in larger elements. Highlighted in bold are factors included in the final model.

However, also in managed forest these broad-leaved tree species stands have been left without economic activity for a long time, because there is no demand for wood of these species in Latvia at present.

Of the broad-leaved tree species included in the study, lime stands had the highest growing stock in the plots. The growing stock found in the plots of this species exceeded 1000 $\mathrm{m}^{3} \cdot \mathrm{ha}^{-1}$, which is unusually large in Latvia. It should be noted that the area of the plot was only $700 \mathrm{~m}^{2}$ and it is likely that in a larger area the growing stock would definitely not be as large. This is because normally larger or smaller gaps are formed, but plots were established to avoid gaps. This large stock was found in a small, fragmentary 186-year-old stand in Jēkabkalns Forest Park, which is an anthropogenically heavily affected stand, since it was originally designed as a park. However, like the rest of the
Table 10. Calculated coefficients for characterising the increment of the growing stock at the forest element level

\begin{tabular}{|c|c|c|c|c|c|}
\hline $\begin{array}{c}\text { Dependent } \\
\text { variable }\end{array}$ & Source & Estimate & SE & $\begin{array}{c}\text { Wald } \\
\text { Chi-Square }\end{array}$ & $p$-value \\
\hline \multirow[t]{9}{*}{$\operatorname{Ln}\left(\mathrm{Z}_{\mathrm{M}}\right)$} & (Intercept) & -1.106 & 0.898 & 1.518 & 0.218 \\
\hline & $\begin{array}{l}\text { Dominant_species } \\
\text { oak }\end{array}$ & 0. & & & \\
\hline & $\begin{array}{l}\text { Dominant_species } \\
\text { lime }\end{array}$ & 0.846 & 0.288 & 8.651 & 0.003 \\
\hline & $\begin{array}{l}\text { Dominant_species } \\
\text { maple }\end{array}$ & 0.713 & 0.261 & 7.454 & 0.006 \\
\hline & $\begin{array}{l}\text { Dominant_species } \\
\text { elm }\end{array}$ & 0.616 & 0.201 & 9.366 & 0.002 \\
\hline & $\operatorname{Ln}(\mathrm{a})$ & -0.212 & 0.185 & 1.309 & 0.253 \\
\hline & ba & 0.069 & 0.008 & 68.154 & $<0.001$ \\
\hline & $\mathrm{RdD}$ & 2.318 & 0.314 & 54.615 & $<0.001$ \\
\hline & $\mathrm{RD}$ & -1.212 & 0.319 & 14.450 & $<0.001$ \\
\hline \multirow[t]{9}{*}{$\operatorname{Ln}\left(Z_{M} G\right)$} & (Intercept) & 1.731 & 0.220 & 62.005 & $<0.001$ \\
\hline & $\begin{array}{l}\text { Dominant_species } \\
\text { oak }\end{array}$ & 0 & & & \\
\hline & $\begin{array}{l}\text { Dominant_species } \\
\text { lime }\end{array}$ & 0.285 & 0.107 & 7.164 & 0.007 \\
\hline & $\begin{array}{l}\text { Dominant_species } \\
\text { maple }\end{array}$ & 0.341 & 0.083 & 16.680 & $<0.001$ \\
\hline & $\begin{array}{l}\text { Dominant_species } \\
\text { elm }\end{array}$ & 0.132 & 0.107 & 1.505 & 0.220 \\
\hline & $\operatorname{Ln}(a)$ & -0.699 & 0.046 & 231.907 & $<0.001$ \\
\hline & $\mathrm{RD}$ & -0.449 & 0.135 & 11.005 & 0.001 \\
\hline & $\mathrm{BAL}+1$ & -0.004 & 0.002 & 2.560 & 0.110 \\
\hline & $\mathrm{RdD}$ & 0.290 & 0.106 & 7.465 & 0.006 \\
\hline
\end{tabular}

$\mathrm{Z}_{\mathrm{M}}$, increment of growing stock $\left(\mathrm{m}^{3} \cdot \mathrm{ha}^{-1}\right) ; \mathrm{Z}_{\mathrm{MG}}$, growth potential $\left(\mathrm{m}^{3} \cdot \mathrm{ha}^{-1} \cdot \mathrm{m}^{-2}\right)$; a, age of element tree (years); ba, element basal area $\left(\mathrm{m}^{2} \cdot \mathrm{ha}^{-1}\right)$; RdD, relative diameter of the element trees (calculated as ratio between element mean diameter and mean diameter of the dominant species trees); RD, stand relative density; BAL, basal area in larger elements $\left(\mathrm{m}^{2} \cdot \mathrm{ha}^{-1}\right)$.

broad-leaved stands, economic activity has not occurred for a long time in that stand. Large stock in lime stands was also found in economically little affected stands, for example, on Liepu Island in Aizkraukle bog and on the former island of Lake Biža (now peninsula) in Andrupene, where the stock of lime stands exceeded $800 \mathrm{~m}^{3} \cdot \mathrm{ha}^{-1}$. Other studies carried out in Latvia also show high yield and superiority of lime stands in terms of yield among other broad-leaved species. Lime trees show higher yield than oaks already at a young age in plantation stands (Daugaviete et al., 2015), as well as higher yield than maples in 61 to 100-year-old stands (Daugaviete et al., 2019). The high yield or potential of lime stands is also indicated in growth tables published in Russia, where lime stands in higher site index classes are projected to reach $800-900 \mathrm{~m}^{3} \cdot \mathrm{ha}^{-1}$, while oak stands in the mixed tree forest zone in the European part of Russia would yield 500-600 $\mathrm{m}^{3} \mathrm{ha}^{-1}$ (Shvidenko et al., 2008). Also in Poland (Jaworski et al., 2005) in unmanaged forests in lime stands had stocks of $760-860 \mathrm{~m}^{3} \cdot \mathrm{ha}^{-1}$.

The results of our study show that the yield of broad-leaved tree stands does not differ significantly between mixed and 
monospecies stands, nor did we find any significant differences between simple and complex stands. Our results are in line with those of other researchers, who showed that the productivity of stands does not differ between monospecies and mixed stands (Jacob et al., 2010; Huskonen et al., 2021). However, there are also a number of studies indicating that mixed stands are more productive than monospecies stands (Paquette and Messier, 2011; Zhang et al., 2012). Different results of the relationship between stand productivity and structure between different studies can be due to the fact that long-term experimental plots are needed for the objective evaluation of these indicators (Zeller and Pretzsch, 2019).

However, the increment of growing stock has a significant relationship with the basal area of stand, which is not surprising, as a stand with larger basal area will have larger increment in growing stock. However, the results of our study also show that the growth potential or growth per unit of basal area is smaller in denser stands. This means that it is very important to manage the stands in such a way as to ensure optimal density of the stand, since only such stands will be able to make full use of this growing space. In overstocked stands, the absolute increment in growing stock will be large, but the trees will be smaller due to competition between trees in these stands. Also, there will be greater annual mortality, which was not taken into account in this study, as stands were visited only once. In contrast, the growth potential of a sparse stand will be high, but the total increment of standing volume will be less, and thus the fertility potential of the soil will not be exploited.

The increment of the growing stock of forest elements, similar as that of the stand level, is an important indicator that characterises competition (relative density) and volume indicators (basal area of the forest element), as well as indicators characterising the social position of the forest element - basal area of larger trees and the relative average basal area of the forest element. A smaller volume of a forest element in relation to other forest elements will result in a smaller increment in its growing stock (at the same level of other factors) and growth potential. This seems to contradict the conclusion that the structure of a stand does not affect the overall growth of the stand. Smaller elements produce less, and therefore the forest elements that are larger produce more, such that the overall growth of the stock is levelled out.

The developed models characterise the increment of growing stock of the surveyed stands over the last ten years, but they cannot be used to predict the growth of stock in broadleaved tree stands. These models and analyses reveal the indicators affecting growth in broad-leaved tree stands in Latvia, but in order to create growth forecast models, it would be necessary to supplement the data, as well as to remeasure existing plots after a period of time. As the growth rate is a dynamic process, growth models need to be developed on re-measured forest data. Also, regarding future growth rate forecasts, data on managed stands would be necessary, as our study plots were mainly established in long-term unmanaged stands. Unfortunately, at present broad-leaved tree species are not of economic interest in Latvia, and therefore their distribution is small and their targeted management is not taking place as a general practice.

Finally, the hypothesis put forward in the study is partially confirmed. There are already productive broad-leaved stands in Latvia, which show that it is already possible to grow high-quality stands of these species. We also found that the yield of broad-leaved stands and individual forest elements depend significantly on age and stand density, but do not significantly depend on the stand structure (mixture and composition).

\section{ACKNOWLEDGEMENTS}

This study was financially supported by the Latvian State Forests Stock Company Research project (2016-2020) "Role of broad-leaved forest stands in sustainable forestry in Latvia".

\section{REFERENCES}

Daugaviete, M., Lazdina, D., Bambe, B., Bardule, A., Bardulis, A., Daugavietis, U. (2015). Productivity of different tree species in plantations on agricultural soils and related environmental impacts. Baltic Forestry, 21 (2), 349-358.

Daugaviete, M., Lazdina, D., Celma, S., Daugavietis, U. (2019). Characteristic growing parameters of small-leaved lime and Norway maple stands in the climatic conditions of Latvia. Acta Biol. Univ. Daugavp., 19 (2), 115-128.

De Jaegere, T., Hein, S., Claessens, H. (2016). A review of the characteristics of small-leaved lime (Tilia cordata Mill.) and their implications for silviculture in a changing climate. Forests, 7 (3), 56.

Donis, J. (2015). Mežaudžu augšanas gaitas un pieauguma noteikšana, izmantojot pārmērītos meža statistiskās inventarizācijas datus [Determining the growth and increment of forest stands using the measured national forest inventory data]. Scientific research report. $75 \mathrm{pp}$. (in Latvian). http://www.silava.lv/userfiles/file/Projektu\%20parskati/2015_Donis_LV M_gala.pdf

Donis, J., Šṇepsts, G. (2019). Novēloti koptu vienvecuma egḷu audžu apsaimniekošanas alternatīvas un to ekonomiskais izvērtējums [Management alternatives of even-aged spruce stands with delayed thinning and their economic assessment]. Grām.: Jansons, J. (ed.). Vienvecuma egḷu meži Latvijā [Even-aged spruce stands in Latvia]. Latvijas Valsts mežzinātnes institūts "Silava" [Latvian State Forest Research Institute "Silava"], Salaspils, pp. 71-98 (in Latvian).

Donis, J., Šṇepsts, G., Zdors, L., Treimane, A. (2019). Augšanas gaitas model̦u pilnveidošana [Improvement of the growth models]. Scientific research report. 61 pp. (in Latvian).

https://www.lvm.lv/petijumi-un-publikacijas/augsanas-gaitas-modelu-pil nveidosana

Dobrovolny, L., Martinik, A., Drvodelic, D., Oršanič, M. (2017). Structure, yield and acorn production of oak (Quercus robur L.) dominated floodplain forests in the Czech Republic and Croatia. South-East European Forestry, 8 (2), 127-136.

Hemery, G. E., Clark, J. R., Aldinger, E., Claessens, H., Malvolti, E. M., O'connor, E., Raftoyannis, Y., Savill, P. S., Brus, R. (2010). Growing scattered broadleaved tree species in Europe in a changing climate: A review of risks and opportunities. Forestry: Int. J. Forest Res., 83 (1), 65-81.

Huuskonen, S., Domisch, T., FinérL, Hantula, J., Hynynen, J., Matala, J., Miina, J., Neuvonen, S., Nevalainen, S., Niemistö, P. (2021). What is the 
potential for replacing monocultures with mixed-species stands to enhance ecosystem services in boreal forests in Fennoscandia? Forest Ecol. Manag., 479, 118558.

Jansons, Ā. (2015). Mežsaimniecības pielāgošana klimata izmain̄ām [Adapting forestry to climate change]. Scientific research report. $53 \mathrm{lpp}$. (in Latvian).

https://www.lvm.lv/images/lvm/Petijumi_un_publikacijas/Petijumi/ MS_pielagosana_klimata_izmainam_2010-2015_kopsavilkums.pdf (accessed 20.08.2021)

Liepa, I. (1996). Pieauguma mācība [Science of Increment]. Latvian University of Agriculture, Jelgava. 123 lpp. (in Latvian).

Jaworski, A., Kołodziej, Z., Bartkowicz, L. (2005). Structure and dynamics of stands of primeval character composed of the little-leaf linden (Tilia cordata Mill.) in the "Las lipowy Obrożyska" Reserve (southern Poland). J. Forest Sci., 51 (7), 283-304

Lexerød, N. L., Eid, T. (2006). An evaluation of different diameter diversity indices based on criteria related to forest management planning. Forest Ecol. Manag., 222, 17-28.

Jacob, M., Leuschner, C., Thomas, F. M. (2010). Productivity of temperate broad-leaved forest stands differing in tree species diversity. Ann. Forest Sci., 67 (5), DOI: 10.1051/forest/2010005.

Paquette, A., Messier, C. (2011). The effect of biodiversity on tree productivity. From temperate to boreal forests. Global Ecol. Biogeogr., 20, 170-180.
Semaškienè, L. (2006). Small-leaved lime (Tillia cordata Mill.) in Lithuania phenotypical diversity and productivity of modal stands. Summary of doctoral dissertation in biomedical sciences, forestry (14B). Kaunas, 23 pp.

Shvidenko, A., Shchepashchenko, D. G., Nilsson, S., Buluy, Y. I. (2008). Tables and Models of Growth and Productivity of Forests of Major Forest Forming Species of Northern Eurasia (Standard and Reference Materials). Federal Agency of Forest Management; Moscow. 886 pp.

State Forest Service (2020). Statistikas pārskats [Statistic review] https://www.zm.gov.lv/valsts-meza-dienests/statiskas-lapas/2020-gads?id $=23045$ (accessed 14.07.2021) (in Latvian).

Thuiller, W. (2004). Patterns and uncertainties of species' range shifts under climate change. Global Change Biol., 10, 2020-2027.

Walther, G. R., Post, E., Convey, P., Menzel, A., Parmesan, C., Beebee, T. J. C., Fromentin, J.-M., Hoegh-Guldberg, O., Bairlein, F. (2002). Ecological responses to recent climate change. Nature, 416, 389-395.

Zeller, L., Pretzsch, H. (2019). Forest ecology and management effect of forest structure on stand productivity in Central European forests depends on developmental stage and tree species diversity. Forest Ecol. Manag., 434, 193-204.

Zhang, Y., Chen, H. Y. H., Reich, P. B. (2012). Forest productivity increases with evenness, species richness and trait variation. A global meta-analysis. J. Ecol., 100, 742-749.

Received 8 March 2021

Accepted in the final form 3 August 2021

\section{PLATLAPJU (QUERCUS ROBUR, TILIA CORDATA, ACER PLATANOIDES UN ULMUS LAEVIS) MEŽAUDŽU PRODUKTIVITĀTE LATVIJĀ}

Klimata prognozes liecina, ka nākotnē klimats kḷūs aizvien piemērotāks platlapju audzēšanai Latvijā. Tādēl ḷoti svarīgi ir jau tagad apzināt un saprast, kāds ir šo platlapju audžu augšanas potenciāls Latvijā un kādi ir krājas pieauguma ietekmējošie faktori. Pētījuma rezultāti liecina par audžu augstu ražǐbu, jau 60-80 gadus vecās audzēs krāja var sasniegt $500-600 \mathrm{~m}^{3} \cdot \mathrm{ha}^{-1}$, bet vēlākos gados pat $700-1000 \mathrm{~m}^{3} \cdot \mathrm{ha}^{-1}$. Mūsu pētîjuma rezultāti liecina, ka audzes un atsevišḳu meža elementu krājas pieaugums un augšanas potenciāls būtiski atškiras starp dažāāām platlapju sugām, kā arī nozīmīgi ietekmējošie faktori ir mežaudzes vai meža elementa vecums, koku savstarpējās konkurences rādītāji (šḳērslaukums un/vai biezība) un atsevišḳa meža elementa līmenī arī meža elementa sociālā stāvokḷa raksturojošie rādītāji (relatīvais caurmērs attiecībā pret mežaudzes pirmā stāva valdošās koku sugas vidējo caurmēru un lielāku meža elementu šķērslaukumu summu). Savukārt starp tīraudzēm un mistrotām audzēm, kā arī starp vienkāršām un saliktām audzēm neesam konstatējuši būtiskas krājas pieauguma un augšanas potenciāla atškirības ne audzes, ne atsevišķa meža elementa līmenī. 